\title{
Impact of predation by greater flamingos Phoenicopterus ruber on the meiofauna, microflora, and sediment properties of two southern African lagoons
}

\author{
D. Glassom*, G. M. Branch \\ Zoology Department, University of Cape Town, Rondebosch 7700, South Africa
}

\begin{abstract}
Responses of meiofauna, bacteria and microalgae to the exclusion of greater flamingos Phoenicopterus ruber were measured intertidally and subtidally at Walvis Bay and intertidally at Sandwich Harbour on the Namibian coast. Sediment properties were also moasured. Meiofauna showed little response at any of the sites. Bacteria decreased in exclosures relative to controls at all sites, but significantly so only at 1 of them. Chlorophyll levels increased at both Walvis Bay sites, but did not respond at Sandwich Harbour, where there was considerably less disturbance by flamingos. Organic content and redox potential of sediments were affected, but the response varied between sites. Overall, disturbance effects were uncertain and inconsistent
\end{abstract}

KEY WORDS: Flamingos Disturbance Chlorophyll Bacteria Melofauna

\section{INTRODUCTION}

Disturbance has well-documented impacts on community structure in soft sediments, and may range in scale from the microscopic (e.g. Reidenauer 1989) to the catastrophic. Agents of disturbance may be physical or biotic, with biological disturbances more important on a smaller scale and larger-scale disturbances resulting mostly from physical causes (Probert 1984). The range of fauna affected by disturbances has similarly been shown to be large and includes bacteria (Branch \& Pringle 1987) and meiofauna (Bell 1980, Reidenauer 1989) as well as macrofauna. Physical and chemical properties of sediments may also be altered. with indirect effects on the biota (Rhoads \& Young 1970, Rhoads 1974, Daborn et al. 1993). Biological disturbances of soft sediments are commonly caused by predation, burrowing or tube building. Predationdisturbance has been documented in a number of animals, including shorebirds.

\footnotetext{
•E-mail: dglassom@botzoo.uct.ac.za
}

Since disturbances can affect interactions between species or trophic levels, a single disturbance may considerably aiter community structure. Despite this, most studies are limited to interactions between pairs of species or specific guilds of species. Exceptions include studies by Branch \& Pringle (1987) and Wynberg (1991). Walters \& Moriarty (1993) recognised the need to measure predator exclusion effects on as wide an assemblage as possible. Finally, the description of a 'cascade' effect, mediated by the presence of intertidal waders (Daborn et al. 1993), emphasises the potential of a single disturbance to affect all levels of a community,

Despite the work done on other shorebirds, little attention has been given to the potential importance of predation by flamingos in structuring estuarine benthic communities. Exclusion of greater flamingos Phoenicopterus ruber from intertidal areas of 2 lagoons on the Namibian coastline, Walvis Bay and Sandwich Harbour, and subtidal areas of Walvis Bay led to significant changes in abundance of macrofaunal species (Glassom \& Branch 1997). This paper will 
investigate any direct or indirect effects of flamingo predation on the benthic meiofauna, bacteria and microalgal stocks and the sediment properties in the 2 lagoons.

\section{METHODS}

Exclusion experiments were done intertidally (April 1989 to July 1990) and subtidally (May 1989 to July 1990) at Walvis Bay, but only intertidally (October 1989 to July 1990) at Sandwich Harbour. At each of the 3 sites, a set of 4 replicate exclosures, measuring $3.5 \times$ $3.5 \mathrm{~m}$, was constructed. Unmarked control plots of an area similar to that of the exclosures alternated with the cages for complete interspersion of treatments. $A$ fuller description of the experiment and cage designs is given in Glassom \& Branch (1997)

Effects of caging were tested by dismantling 2 sides of half the cages of each set on the penultimate sampling date (cage control), and comparing samples collected from cage controls on the final sampling date with those from whole cages. Intertidally at Walvis Bay, the remaining cages disappeared between these 2 dates. This meant that no data were obtained for cage controls at this site.

Sediment. Organic content of sediment: Sediment was sampled to a depth of $20 \mathrm{~cm}$ using a core with a diameter of $21 \mathrm{~mm}$. Since no adequate facilities for freezing samples were available, they were sun dried until they could be frozen. Organic content of the sediment was determined by placing oven dried, pre-weighed samples in a muffle furnace at $450^{\circ} \mathrm{C}$ for $4 \mathrm{~h}$ to burn off all organic matter and re-weighing them. Organic content is expressed as $\mathrm{mg} \mathrm{g}^{-1} \mathrm{dry}$ sediment.

Sediment particle size: Dry sediment samples were sifted through nested sieves of mesh sizes 710,500 , $300,150,106$ and $63 \mu \mathrm{m}$. The weight of each fraction was calculated as a percentage of the total mass. Sieve mesh sizes were converted to $\Phi$ for presentation and analysis.

Chemical properties: In January 1990, pH and redox potential were measured at all sites in the field using a portable Crison pH meter. All measurements were taken just below the sediment surface.

Microalgal standing stocks. Approximately $1 \mathrm{~g}$ of sediment was collected from the sediment surface, wrapped in aluminium foil and frozen until processed. Samples were weighed, placed into stainless steel tubes with a pinch of $\mathrm{MgCO}_{3}$ and $10 \mathrm{ml}$ acetone, ground for 3 min and stored in the dark at $4^{\circ} \mathrm{C}$ for $48 \mathrm{~h}$. They were then centrifuged, and the supernatant extracted. Total chlorophyll was determined by reading optical densities (OD) at 750,664,647 and $630 \mathrm{~nm}$.
After subtracting the reading obtained for $750 \mathrm{~nm}$ from each of the others, to correct for turbidity, chlorophyll concentrations ( $\mu \mathrm{g}$ chlorophyll $\mathrm{g}^{-1}$ sediment) were calculated using the formula from Branch \& Pringle (1987):

$$
\begin{aligned}
\mu \mathrm{g} \text { chlorophyll }= & 21.78(\mathrm{OD} 630)+11.89(\mathrm{OD} 647)+ \\
& 4.75(\mathrm{OD} 630)
\end{aligned}
$$

Bacteria. Samples of $5 \mathrm{ml}$ each were taken from the sediment surface using a cylindrical corer and fixed in $4 \%$ formalin in $0.2 \mu \mathrm{m}$ filtered seawater. All samples were stored in the dark at $4^{\circ} \mathrm{C}$ until counted.

Bacterial numbers were determined by direct count under fluorescent microscopy after being stained with DAPI. Bacteria were separated from sediment particles by addition of tetrasodiumpyrophosphate followed by sonication for 5 min (Velji \& Albright 1986). Samples were then stained with DAPI at $5 \mu \mathrm{g} \mathrm{ml} \mathrm{m}^{-1}$ and incubated in the dark for $20 \mathrm{~min} ; 2 \mathrm{ml}$ samples were then filtered at $178 \mathrm{~mm} \mathrm{Hg}$ onto $0.2 \mu \mathrm{m}$ nuclepore filters that had been pre-stained with irgalan black. To ensure even distribution of bacteria on the filter, $1 \mathrm{ml}$ of a detergent (photo-flow) was filtered prior to the sample. At least 20 fields or 400 bacteria were counted for each sample. Due to logistical constraints, bacteria were sampled only at the beginning and end of the experiment at each site.

Meiofauna. All meiofaunal samples were taken with a core with a cross-sectional area of $6.3 \mathrm{~cm}^{2}$, to a depth of $5 \mathrm{~cm}$. Samples were fixed in $7 \%$ formalin in filtered seawater. Meiofauna were extracted by washing the sample at least 4 times through a $63 \mu \mathrm{m}$ sieve. This method attained an extraction rate of approximately $90 \%$ (authors' pers. obs.), but may exclude hard bodied meiofauna such as bivalves (Wynberg 1991). Extracted meiofauna were stained with Rose Bengal, identified to the level of major groups, and counted. Data are expressed as no. $\mathrm{cm}^{-3}$ sediment.

Treatment effects were analysed using nested ANOVAs in the generalised linear models procedure of SAS. Date was treated as a main effect and analysed for its interaction with treatment. This is equivalent to using a repeated measures analysis. Where multiple comparisons were required, the Contrast procedure of SAS was used (Freund et al. 1986). Error bars on the figures represent the standard errors of the data.

\section{RESULTS}

\section{Physical characteristics of sediments}

Particle size analyses showed little difference between treatments at any site (Table 1). All 3 sites had median particle sizes of between $1.25 \Phi$ and $1.50 \Phi$ for 


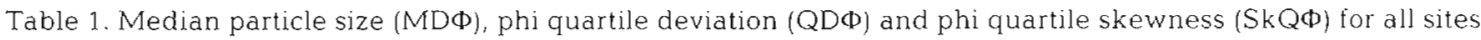

\begin{tabular}{|c|c|c|c|c|c|c|}
\hline & \multicolumn{2}{|c|}{ MDФ } & \multicolumn{2}{|c|}{ QDФ } & \multicolumn{2}{|c|}{$\mathrm{SkQ} \Phi$} \\
\hline & Exclusion & Control & Exclusion & Control & Exclusion & Control \\
\hline Walvis Bay intertidal & 1.25 & 1.40 & 0.30 & 0.30 & -0.15 & 0.00 \\
\hline Walvis Bay subtidal & 1.40 & 1.40 & 0.30 & 0.30 & -0.10 & -0.10 \\
\hline Sandwich Harbour intertidal & 1.50 & 1.30 & 0.68 & 0.50 & 0.03 & -0.05 \\
\hline
\end{tabular}

treatments and controls. QDФ (quartile deviation) and SkQФ (quartile skewness) were also similar between treatments and controls.

Fig. 1 illustrates the effects of excluding flamingos on sediment properties. Organic contents of the sediments in exclusion cages were statistically different from controls at Sandwich Harbour $(F=4.40, \mathrm{p}=0.037$, $\mathrm{df}=1$ ). At Walvis Bay, the difference was less pronounced (intertidally $F=3.65, p=0.055$, df $=1$; subtidally $F=3.18, \mathrm{p}=0.077$, $\mathrm{df}=1$ ). Exclusion plots had lower organic content than the controls at Walvis Bay intertidal, but the reverse occurred at the other 2 sites.

Sediment $\mathrm{pH}$ was higher inside the exclosures than in controls at the Walvis Bay intertidal site but higher in control areas at the other 2 sites. However, none of these differences were statistically significant. Redox potential, indicative of oxygen content of the sediment differed between caged and control areas only at Sandwich Harbour $(F=9.69, p=0.0060$, df $=1)$. At all 3 sites, the redox potential was strongly negative, indicating hypoxic or anoxic sediments (Fig. 1).

\section{Microalgal standing stocks}

Chlorophyll concentrations (Fig. 2) differed significantly between treatments and controls at Walvis Bay intertidal $(F=10.45, \mathrm{p}=0.018)$ and subtidal $(F=16.15$, $\mathrm{p}=0.007)$, but not at Sandwich Harbour $(F=0.13, \mathrm{p}=$ 0.731), which also had the least temporal variation. At Walvis Bay intertidal, the chlorophyll concentrations were consistently higher within exclosures than in controls, the contrast becoming more obvious at each successive sampling date. At the Walvis Bay subtidal site, chlorophyll levels rose progressively in the exclosures. Concentrations in the cage controls for July 1990 were lower at both sites than in either caged or control areas, but were closer to concentrations in control areas than in cages.

\section{Bacteria}

Bacterial numbers (Fig. 3) were compared at the beginning and end of the experiment at each site. Ini- tially no significant differences existed between bacterial numbers in cages and controls at any of the sites and there was no suggestion of any pattern in the results. By the end of the study, numbers of bacteria in control areas were substantially higher than in ex-
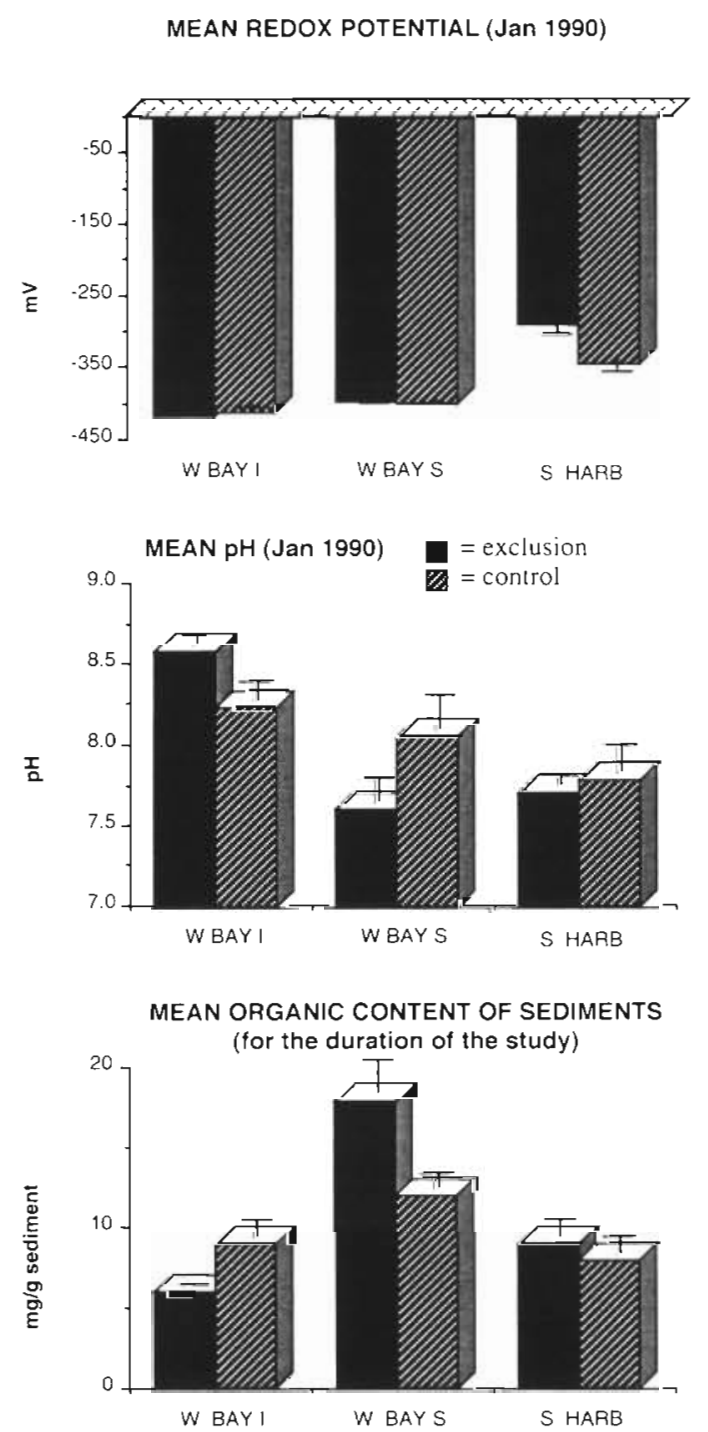

Fig. 1 Physical properties of sediments at the study sites. $W$ BAY 1: Walvis Bay intertidal, W BAY S; Walvis Bay subtidal, and S HARB: Sandwich Harbour intertidal. Values are means + SE 

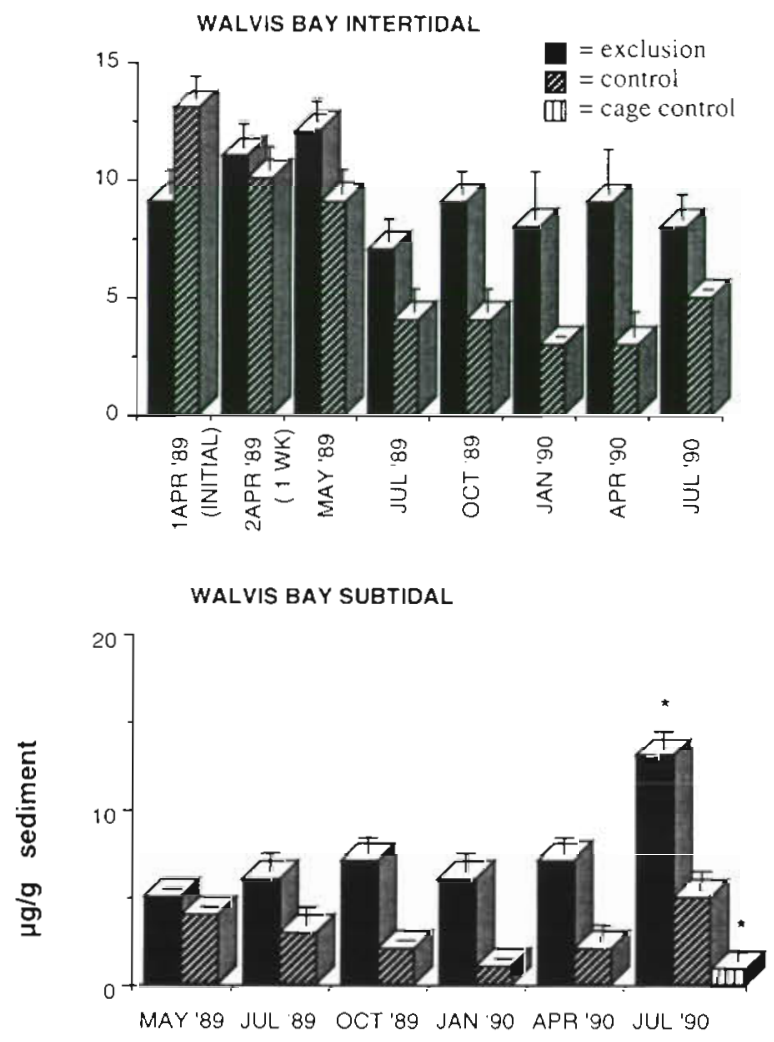

SANDWICH HARBOUR

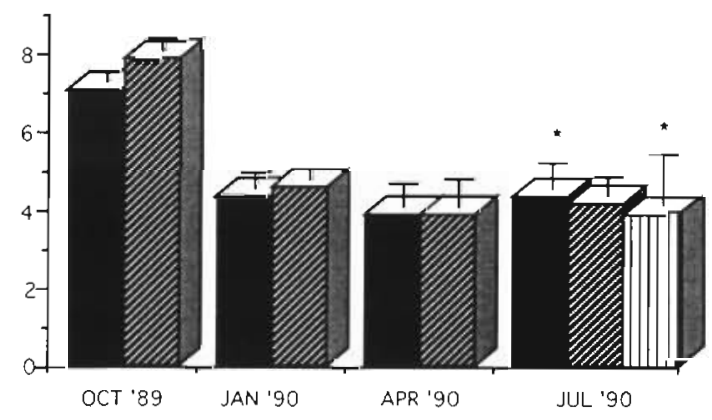

Fig. 2. Chlorophyll concentrations at the study sites. Values are means $+\mathrm{SE} . \mathrm{n}=4$, except for * where $\mathrm{n}=2$

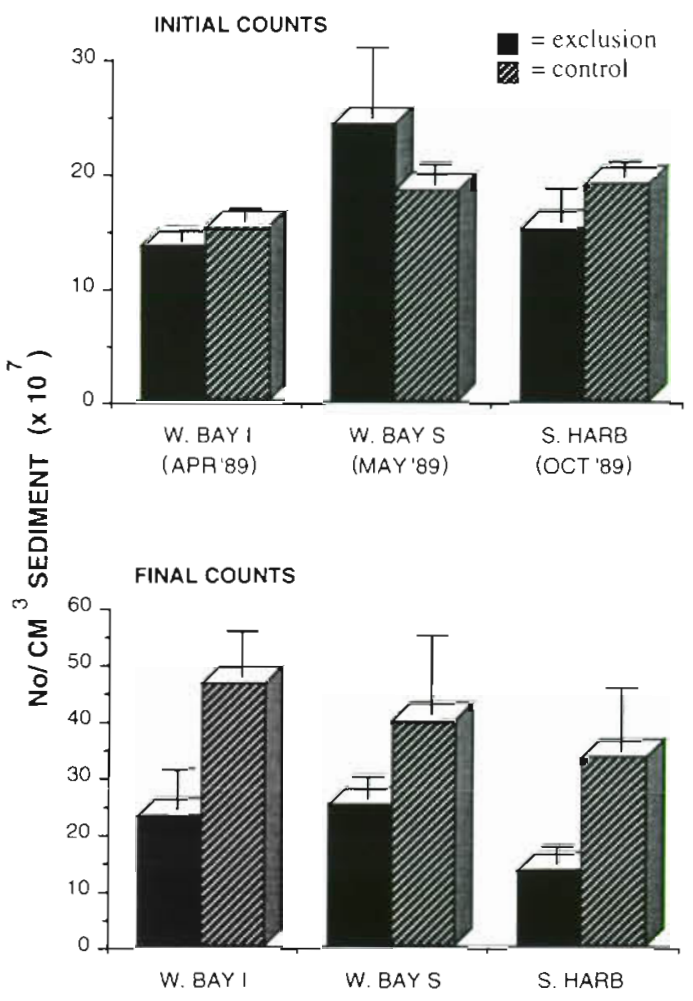

Fig. 3. Numbers of bacteria at the beginning and end of the study. Values are means $+\mathrm{SE}$

clusion areas at all sites. Only at Sandwich Harbour, however, was the difference statistically significant $(F=6.67, \mathrm{p}=0.029, \mathrm{df}=1)$. At Walvis Bay intertidal $F=4.64, \mathrm{p}=0.075$ and $\mathrm{df}=1$, while subtidally $F=0.36$, $\mathrm{p}=0.581$, and $\mathrm{df}=1$. Bacterial counts were close to estimates by Tibbles (1991) for Walvis Bay.

\section{Meiofauna}

Table 2 summarizes mean meiofaunal numbers, and the effects of date and treatment. Meiofauna at Walvis

Table 2. Mean meiofaunal numbers $\left(\mathrm{cm}^{-3}\right.$ sediment) for the entire time of the experiment excluding the initial sampling date

\begin{tabular}{|c|c|c|c|c|c|c|c|c|c|c|c|c|}
\hline & \multicolumn{4}{|c|}{ Walvis Bay intertidal } & \multicolumn{4}{|c|}{ Walvis Bay subtidal } & \multicolumn{4}{|c|}{ Sandwich Harbour } \\
\hline & \multirow{2}{*}{ Exclusion } & \multirow{2}{*}{ Control } & \multicolumn{2}{|c|}{ ANOVA } & \multirow{2}{*}{ Exclusion } & \multirow{2}{*}{ Control } & \multicolumn{2}{|c|}{ ANOVA } & \multirow{2}{*}{ Exclusion } & \multirow{2}{*}{ Control } & \multicolumn{2}{|c|}{ ANOVA } \\
\hline & & & $F$ & $p$ & & & $F$ & p & & & $F$ & $\mathrm{p}$ \\
\hline Nematodes & 46.77 & 45.37 & 2.09 & 0.15 & 18.87 & 15.20 & 1.07 & 0.305 & 19.65 & 18.15 & 0.46 & 0.638 \\
\hline Foraminifera & 0.65 & 0.50 & 0.33 & 0.56 & 1.37 & 1.26 & 0.60 & 0.443 & 9.82 & 12.92 & 3.22 & 0.077 \\
\hline Copepods & 10.09 & 10.94 & 4.00 & 0.093 & 5.11 & 5.59 & 0.19 & 0.660 & 2.62 & 0.79 & 13.61 & 0.008 \\
\hline Ostracods & 1.23 & 0.77 & 6.78 & 0.011 & 1.16 & 0.65 & 0.53 & 0.469 & 12.38 & 15.79 & 0.45 & 0.644 \\
\hline Total meiofauna & 58.54 & 56.82 & 2.14 & 0.147 & 26.50 & 22.75 & 0.10 & 0.757 & 44.29 & 47.72 & 0.27 & 0.770 \\
\hline
\end{tabular}


Bay showed little response to caging, with only ostracods $(F=6.78, \mathrm{p}=0.011, \mathrm{df}=1)$ increasing significantly in intertidal exclosures relative to controls. Numbers of copepods also increased substantially at this site, but the increase was not statistically significant $(F=4.00$, $\mathrm{p}=0.093, \mathrm{df}=1$ ). Subtidally, no treatment effects were discerned. At Sandwich Harbour, densities of foraminiferans $(F=3.22, \mathrm{p}=0.077, \mathrm{df}=1)$ showed some treatment effects, but only numbers of copepods $(F=13.61$, $\mathrm{p}=0.008, \mathrm{df}=1$ ) were statistically different between treatments and controls. While the norm seemed to be increased density inside exclosures, foraminiferans at Sandwich Harbour were lower in exclusion than in control areas. Total meiofaunal density was higher inside the exclosures at both Walvis Bay sites, but lower at Sandwich Harbour, although none of these differences were statistically significant.

Fig. 4 shows results for meiofaunal groups at each sampling date. Nematodes at Walvis Bay intertidal showed an erratic response to flamingo exclusion with abundances inside exclosures ranging above and below those of control areas. In the subtidal zone at Walvis Bay, nematodes increased in abundance inside the cages, but this response was largely contingent on the treatment effects on a single sampling date, July 1990. No clear pattern was apparent on other dates and it is doubtful that the difference in means is representative of an overall long-term pattern. At Sandwich Harbour, nematodes were generally more abundant inside cages, but not significantly so.

Foraminifera displayed a more consistent response at Walvis Bay intertidal, being consistently more abundant inside cages, between May 1989 and April 1990. At the subtidal site densities were higher inside the cages, but, again, this response was only clearly evident on the last sampling date. At Sandwich Harbour, the abundances of foraminifera were consistently higher in control areas than in cages. Copepod abundance rose at both intertidal sites. At the subtidal site the response was erratic, and no pattern emerged. Ostracods reacted differently at each site, increasing inside exclosures at Walvis Bay intertidal, decreasing in them at Sandwich Harbour, and oscillating at Walvis Bay subtidal. Only the first of these results was statistically significant.

Patterns displayed by the total meiofauna closely followed those displayed by the nematodes. Densities were lower inside the cages at Sandwich Harbour, but higher at the other 2 sites, although none of the sites showed statistically significant responses in total meiofaunal abundance. Overall the responses of the meiofauna to flamingo exclusion were both site- and taxonspecific.

Both Walvis Bay sites were largely nematode dominated (Fig. 5). At Sandwich Harbour, nematodes still constituted the largest group, but made up a considerably smaller proportion of the total. Ostracods contributed a surprisingly large proportion of the meiofauna at Sandwich Harbour. Copepods, the second largest group at Walvis Bay, comprised the smallest proportion of meiofauna at Sandwich Harbour. Further, the relative abundance of copepods decreased in the controls at Sandwich Harbour, while marginally increasing in controls at Walvis Bay. At Sandwich Harbour, the proportional abundance of ostracods increased within controls. Overall, however, changes in density seemed to have little effect on the relative proportions of meiofaunal groups.

\section{Cage controls}

Chlorophyll levels and abundances of meiofaunal groups were compared among cage controls, full cages and control areas using Contrast for the data of July 1990. Chlorophyll concentrations in cage control areas did not differ significantly from either controls or cages at either of the sites tested. Of the 10 tests done on meiofauna, 3 indicated that the cage controls differed significantly from the exclosures. These were nematodes at Walvis Bay $(F=6.93, \mathrm{p}=0.0164$, df $=1)$, copepods at Walvis Bay $(F=4.45, p=0.0484, \mathrm{df}=1)$, and total meiofauna at Walvis Bay $(F=8.61, p=0.0085, \mathrm{df}=$ 1). Of these, nematodes and total meiofauna also differed significantly between exclosures and control areas $(F=9.06, \mathrm{p}=0.007, \mathrm{df}=1$; and $F=13.52, \mathrm{p}=$ $0.002 \mathrm{df}=1$ respectively). The controls differed statistically from cage controls only for copepods at Sandwich Harbour $(F=4.81, \mathrm{p}=0.044, \mathrm{df}=1)$. The remaining 6 tests showed no significant differences between any of the treatments.

\section{DISCUSSION}

\section{Physical properties of sediments}

Caging effects on sediment properties was variable Neither particle size nor $\mathrm{pH}$ changed significantly at any of the sites. Redox potential (Eh) was affected by treatment only at Sandwich Harbour. Effects on the organic content of sediments were most pronounced at Sandwich Harbour and least at Walvis Bay subtidal.

Many of the physical properties of sediments are interdependent. For example, Plante et al. (1989) found links between sediment grain size, organic content and redox potential, and Reise (1985) correlated time of day and tidal level with Eh. In our study, Eh, $\mathrm{pH}$ and organic content were all lowest at Sandwich Harbour, which also had slightly finer sediment than 
WALVIS BAY INTERTIDAL

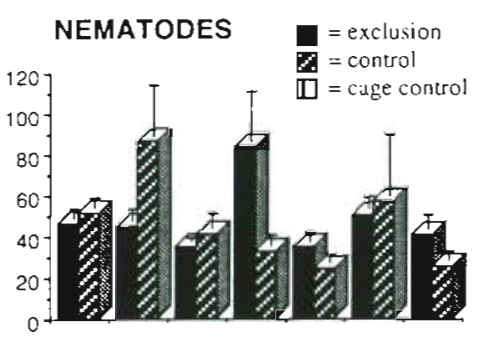

FORAMINIFERA
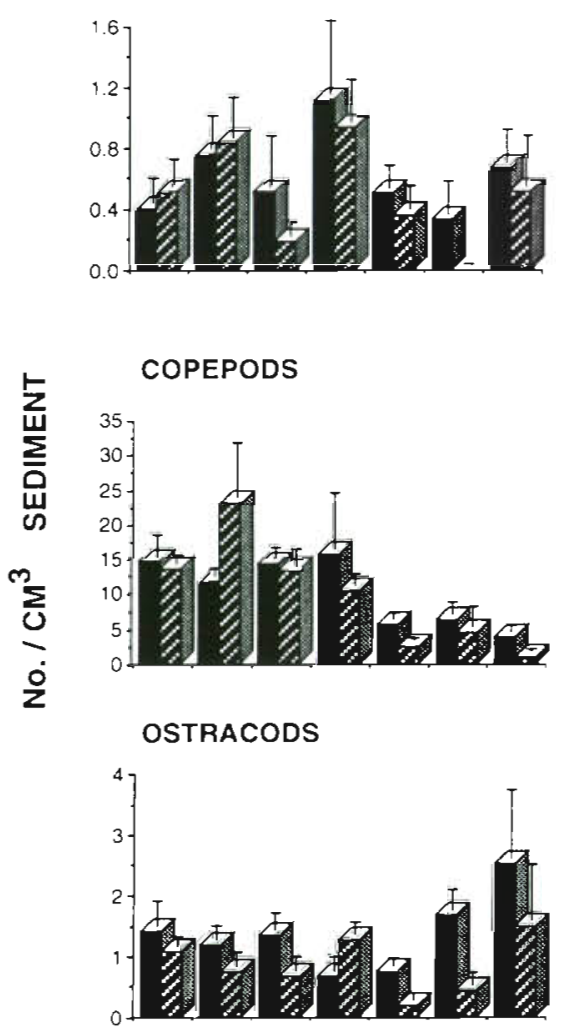

TOTAL MEIOFAUNA

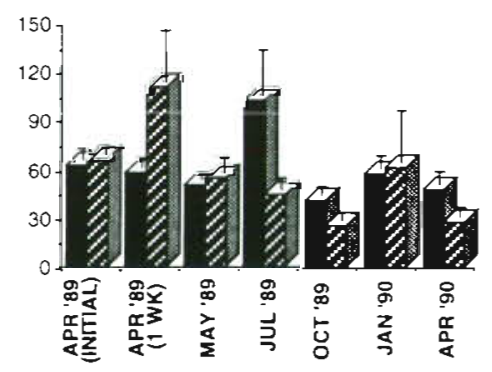

WALVIS BAY SUBTIDAL

SANDWICH HARBOUR
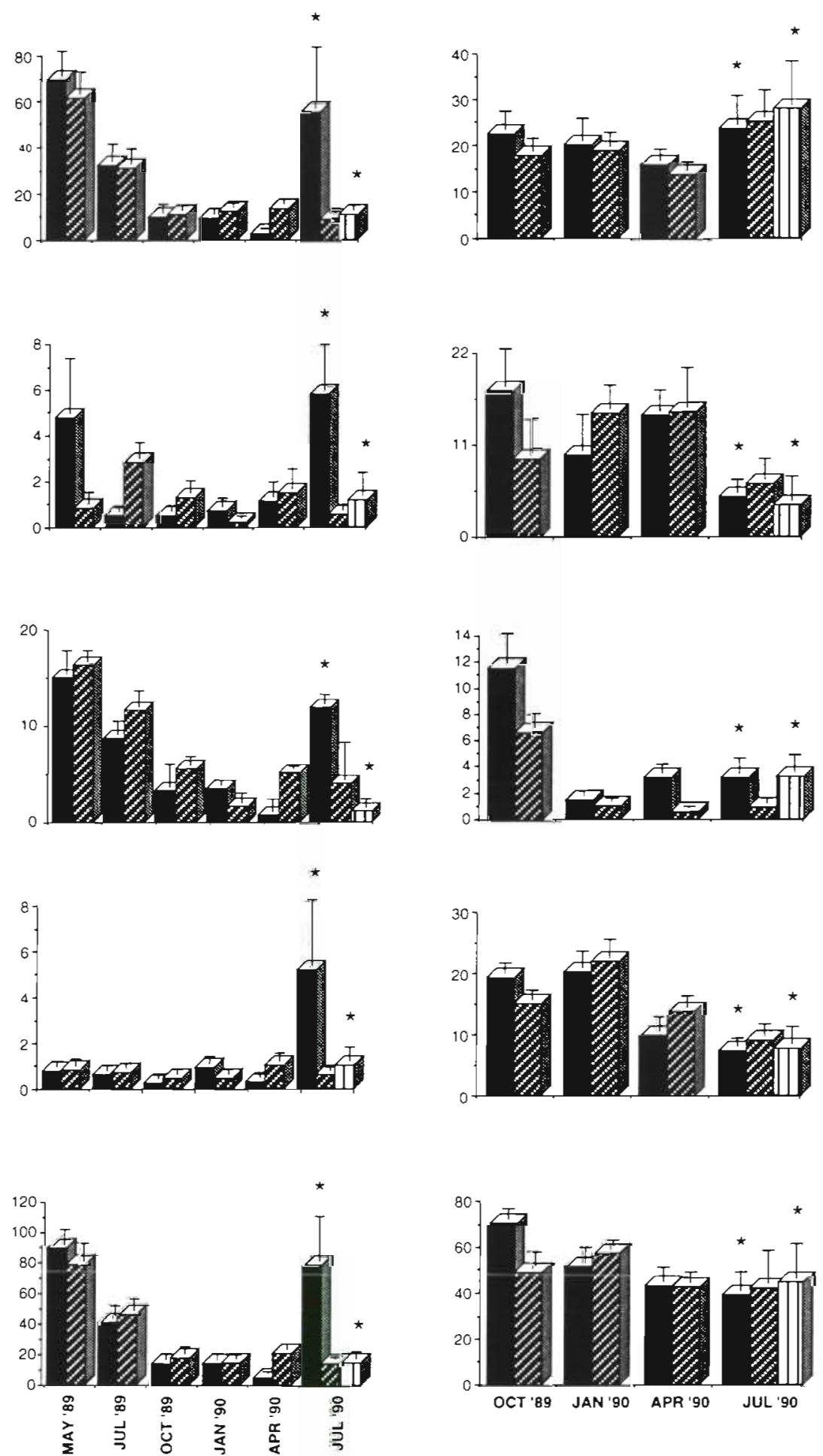

Fig. 4. Abundance of the major meiofaunal groups throughout the study. Values are means + SE. $n=4$, except for ${ }^{+}$where $n=2$

the other 2 sites. Nevertheless, all sites had strongly reducing sediments, with Eh values -330 to $-420 \mathrm{mV}$ in control areas (Fig. 1) despite the fact that readings were taken near to the surface and at times when Eh should have been at its highest. Under similar conditions, positive redox values were obtained at Bogue 

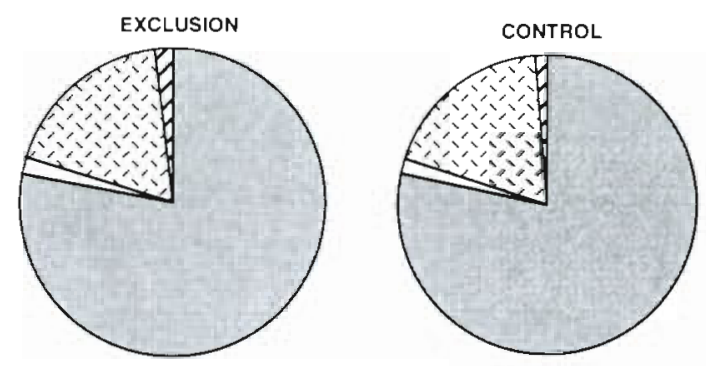

WALVIS BAY INTERTIDAL
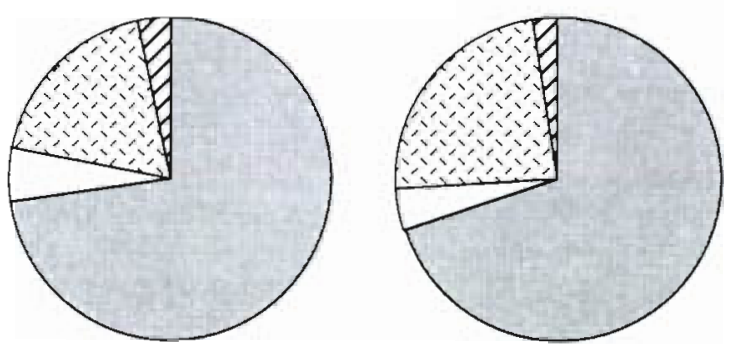

WALVIS BAY SUBTIDAL

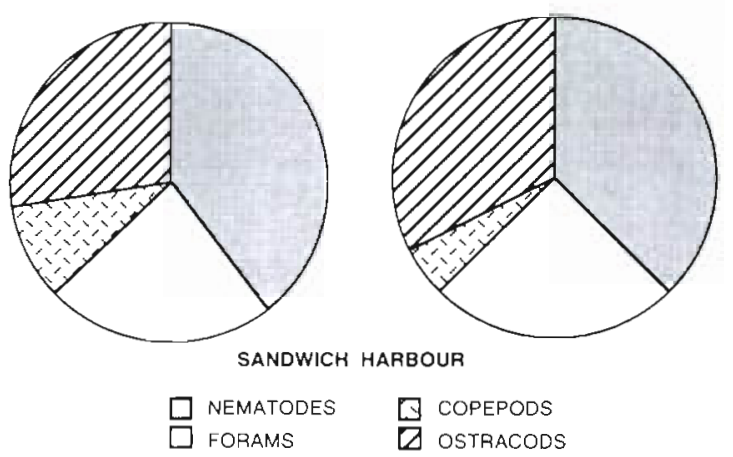

Fig. 5. Proportion of meiofaunal groups for each site and treatment for the duration of the experiment

inlet in North Carolina, USA (Ott \& Machan 1971 cited in Reise 1985); at Langebaan lagoon, on the South African west coast, B. J. Tibbles (pers comm.) obtained minimum Eh readings of ca $-1.90 \mathrm{mV}$

Of the 3 sites, only Sandwich Harbour showed significant treatment effects for Eh, with lower values in control areas than in exclosures. This was also the only site where bacteria were significantly more abundant in control areas than in exclosures, and it is possible that growth of anaerobic bacteria, such as methanogens and sulphate reducers, affected redox potential.

Organic content of the sediment was different between treatments and controls at all sites. Higher organic content is normally associated with lower Eh, but the reverse was true at Sandwich Harbour. At Walvis Bay subtidal and Sandwich Harbour intertidal organic contents of sediments were higher inside exclosures than in controls, but differed at Walvis Bay intertidal by being higher in control areas. Total meiofauna were higher inside exclosures, and may have contributed to the elevation of organic content at 2 sites.

In general, changes of sediment properties were limited and inconsistent between sites, and no obvious patterns emerged which could have explained the observed changes in the biota.

\section{Chlorophyll}

Since the chlorophyll samples were taken from the sediment surface, it was expected that the less disturbed sediment inside the exclosures would have higher chlorophyll content, despite the presence of higher numbers of nematodes and copepods which feed on microalgae (Blanchard 1991). Ampeliscid amphipods also feed on microalgae (Mills 1966), and this was expected to influence results, particularly subtidally at Walvis Bay. At both Walvis Bay sites, but not at Sandwich Harbour, chlorophyll concentrations in exclosures increased relative to controls as expected At Walvis Bay subtidal the treatment effect may have been exaggerated by the fact that the sediment surface was elevated above that of surrounding areas, due to the development of dense mats of ampeliscid tubes. This meant that caged areas became exposed at spring low tides when much of the sampling was done. Such exposure could have led to increased productivity and accounted for the increase in chlorophyll concentration in the exclosures (Fig. 2). It is possible that diatoms were buried by disturbance associated with flamingo feeding, as Branch \& Pringle (1987) have described for the activities of the sand-prawn Callianassa kraussii. Since we sampled only surface microalgae, total chlorophyll concentrations may have been underestimated in control areas. At Sandwich Harbour, there was less visible sign of sediment turnover by flamingoes, and the lack of treatment effects on chlorophyll concentration may reflect this

\section{Bacteria}

By the end of the experiment, numbers of bacteria were lower inside than outside exclosures at all sites (Fig 3), although the difference was significantly different only at Sandwich Harbour. This is somewhat anomalous, because organic content was higher inside exclosures than in control areas at 2 sites. Since organic materials are needed for bacterial metabolism it would be expected that bacterial numbers and organic content of sediment should be positively correlated (Mazure \& Branch 1979). This was true only of 
Walvis Bay intertidal. However, organic content and particle size may be poor predictors of bacterial abundance within particular sediments (Cammen 1982). Cammen \& Walker (1986) found that fluctuations in bacterial abundance were positively correlated with changes in microalgal density in the Bay of Fundy. In the present study, microalgal abundance was higher inside exclosures at 2 sites, but bacterial density remained higher in control areas. Meiofaunal predation has been shown to affect bacterial density in soft sediments (Walters \& Moriarty 1993), and most of this effect could be attributed to nematode predation. However, neither overail meiofaunal density nor the relative proportion of nematodes in exclusion and control plots suggested that this was a tenable hypothesis for the depression of bacterial numbers inside cages. It is, however, likely that grazing by macrofauna, which were dominated by deposit feeders (Glassom \& Branch 1997), would have significantly affected bacterial abundance

Branch \& Pringle (1987) showed that bacterial abundance increases in the presence of the sand-prawn Callianassa kraussi, which is an important bioturbator of the sediment in areas where it is abundant. However, many of the bacteria were concentrated around the burrows of C. kraussi, and bioturbation alone may not cause increases in bacterial abundance. Nevertheless, the possibility exists that exclusion of flamingos contributed to declines in bacteria because bioturbation was reduced inside cages.

\section{Meiofauna}

Bell (1980) demonstrated that exclusion of macroepifauna could significantly increase meiofaunal abundance. However, Reise (1979) considered that infaunal macrofauna, although preying on meiofauna, rarely obtain the majority of their nutritional requirements from this source, and that macrofaunal predation alone is unlikely to significantly reduce meiofaunal populations. Results of macroepifaunal predation experiments on copepods (Webb \& Parsons 1991) support this conclusion. However, predation within the meiofauna, or physical factors such as sediment reworking by macrofauna, could additionally influence meiofaunal abundance (Reise 1979). In our study, top meiofaunal predators such as turbellaria were absent. Since other meiofauna, such as nematodes, were not identified to species level, it is not possible to estimate the proportion of predators amongst the meiofauna and hence the effect of internal predation. Furthermore, other negative or amensalistic effects between meiofaunal species have been demonstrated (Chandler 1989) and such interactions could not be estimated here. Bell
(1980) found that exclusion of macroepifauna in a salt marsh could affect meiofaunal densities, but that these effects differed between taxa and were subject to seasonal variation. Reidenauer (1989) also found taxonspecific reactions to sediment disturbance. Our results bear out this assertion, but indicate that meiofaunal reactions to disturbance may be site specific as well, since taxa responded differently to flamingo exclusion at different sites; however, this was not positively ascertained, because disturbance intensity also differed between sites. Nematodes were the only group that increased within the exclosures at all sites, although this increase was not significant at any of them. Fluctuations in density between treatments was common, and could not consistently be attributed to seasonal changes.

Meiofauna are susceptible to disturbances that alter the oxygen content of the sediment, even if they are not directly preyed upon by the bioturbator (Sherman \& Coull 1980). However, meiofaunal communities are resilient (Alongi 1985), and recolonisation of such areas, particularly after single disturbances, may be rapid (Sherman \& Coull 1980, Billheimer \& Coull. 1988). Meiofauna are adversely affected by high densities of Capitella capitata and other tubiculous colonisers (Alongi \& Tenore 1985), although this could not be demonstrated to be due to disturbance of surface sediments alone (Alongi 1985). Of our 3 study areas, 2 were dominated by $C$. capitata, and the third by tube-building amphipods and C. capitata (Glassom $\&$ Branch 1997). All these species increased significantly in exclosures, and may to some extent have offset the expected positive effects of flamingo exclusion on meiofauna abundance. Finally, the flamingos fed intermittently at the experimental sites, with periods of up to several days lapsing between feeding events and the time lapses could not be accurately ascertained at the time of sampling. Continuous disturbance of sediments by calianassid prawns results in depression of meiofaunal numbers over long time periods (Branch \& Pringle 1987), but meiofaunal recolonisation of intermittently disturbed patches has been shown to occur within 1 tidal cycle or less (Sherman \& Coull 1980). Thus it is possible that control areas had been recolonised between the time they were disturbed by flamingos and the time of sampling. Hence, although. there was apparently a long-term effect caused by flamingo exclusion for some meiofaunal groups, there was little overall change. This could be ascribed to other factors which may have offset the effects of flamingo exclusion.

Well-documented influences on community structure in soft sediments include competition, predation and disturbance. Amensalistic interactions are also frequent. However, a single model for community 
structure in soft sediments has yet to emerge. This study attempted to examine the effect of a predator on benthic community structure. In conjunction with a companion paper looking at effects on macrofauna (Glassom \& Branch 1997) it gives an overview of the effect of a single, top predator on all levels of a softsediment community. To our knowledge, few other studies have done this, exceptions being Branch \& Pringle (1987) and Wynberg (1991). In our study, the disturbance associated with flamingo feeding affected different levels of the benthic biota to varying degrees. The most apparent and dramatic response to removal of the disturbance was among the macrofauna, which were most directly affected by predation and disturbance. Almost all species of macrofauna reacted to caging, with most of them increasing significantly in abundance inside exclosures. Total macrofaunal abundance was similarly affected at all sites, with the magnitude of the response being greatest subtidally, where faunal density in exclosures reached 3 times that in control areas (Glassom \& Branch 1997)

Other taxa displayed secondary effects of disturbance to varying degrees. Densities of meiofauna increased marginally, without radically changing the taxonomic composition of any site. Expectations that meiofauna would suffer effects of sediment disturbance were largely unfulfilled. Interactions between meiofaunal taxa or between macro- and meiofauna which may have prevented substantial responses of meiofauna to flamingo exclusion need further investigation.

Bacteria seemed uniformly negatively affected by the absence of flamingos, although the response was statistically significant in only 1 case. In addition to increased grazing pressure in exclosures, reduced sediment bioturbation may have inhibited bacterial growth to account for these differences.

Microalgal abundance increased in exclosures at both Walvis Bay sites, and provided the clearest indication of effects of sediment disturbance. At Sandwich Harbour, there was little change between treatments, but there were relatively few flamingos there (maximum 500, compared to 12000 greater and at least as many lesser flamingos at Walvis Bayl, and the lack of response at this site tends to reinforce the conclusion that the differences at Walvis Bay are due to the intense sediment disturbance.

\section{CONCLUSION}

From changes in the abundances of macrofauna meiofauna, and bacteria and chlorophyll concentrations after exclusion of flamingos, it is clear that flamingos influenced the benthos of the sites studied. Since some of the species affected were not prey items of flamingos, and these effects were not all accounted for by other biological interactions, some part of this effect can be attributed to disturbance of the sediment, independent of removal of prey by the flamingos.

It seems unlikely that any single factor controls community structure in the absence of this predation and disturbance. There was no evidence that competition was an important factor: nor was there reason to believe that a mosaic of patches of the type proposed by Grassle \& Sanders (1973) was responsible for patterns observed, although recolonisation of completely defaunated patches was not investigated. Sediment properties were mildly altered in exclosures, but this was more likely the result of changes in the biotic community than the cause of them. Since physical sediment properties were not substantially altered in exclosures and changes in chemical properties were not associated with expected changes in bacteria and chlorophyll concentrations, we suggest that the patterns observed are more parsimoniously explained by changes in the macrofauna. All sites became dominated by tube-building, deposit-feeding animals, and amensalistic interactions would have been likely at the high densities achieved, particularly in the subtidal zone at Walvis Bay, where macrofaunal densities exceeded 50000 ind. $\mathrm{m}^{-2}$ (Glassom \& Branch 1997). However, there was no indication of such interactions significantly affecting any taxon.

The decline in abundance of macrofaunal species toward the end of the experiment (Glassom \& Branch 1997) was independent of experimental treatments and was probably the result of physical processes. Apart from predation, physical disturbance, primarily due to wind-blown sediment, may be one of the major factors controlling community structure.

Flamingo exclusion could be seen as causing a chain effect, with the response most obvious among the macrofauna, which would have been most directly affected by predation and had the slowest turnover. At lower trophic levels, there was less direct predation effect, and higher rates of turnover, resulting in more rapid recovery from disturbance. As a result, responses at these levels were ambiguous or completely absent. Lower down the chain, the effects of exclusion also became less predictable.

Acknowledgements. Dr A. Williams and the staff of Walvis Bay Nature Conservation provided lab space and much logistical support. We are grateful to Namibian Nature Conservation for permission to work at Sandwich Harbour, and for use of the accommodation there. Numerous assistants volunteered their time and effort in the field. The project was funded by the Foundation for Research Development (FRD) and by a generous donation from Walvis Bay Salt Refineries. 


\section{LITERATURE CITED}

Alongu DM (1985) The effect of physical disturbance on population dynamics and trophic interactions among microbes and meiofauna. J Mar Res 43:351-364

Along. DM. Tenore KR (1985) The effect of detritus supply on trophic relationships within experimental benthic food webs. 1. Meiofauna-polychaete (Capitella capstata (Type 1) Fabricus) interactions. J Exp Mar Biol Ecol 88:153-164

Bell SS (1980) Meiofauna-macrofauna interactions in a high salt marsh habitat. Ecol Monogr 50(4):487-505

Billheimer LE, Coull BC (1988) Bioturbation and recolonization of meiobenthos in juvenile spot (Pisces) feedng pits. Estuar Coast Shelf Sci 27:335-340

Blanchard GF (1991) Measurement of meiofauna grazıng rates on microphytobenthos: is primary production a limiting factor? J Mar Biol Ecol 147:37-46

Branch GM. Pringle A (1987) The impact of the sand prawn Callianassa kraussi Stebbing on sediment turnover and on bacteria, meiofauna and benthic microflora. J Exp Mar Biol Ecol 107:219-235

Cammen LM (1982) Effect of particle size on organic content and microbial abundance within four marine sediments. Nar Ecol Prog Ser 9:273-280

Cammen LM, Walker JA (1986) The relationship between bacteria and micro-algae in the sediment of a Bay of Fundy mudflat. Estuar Coast Shelf Sci 22:91-99

Chandler GT (1989) Foraminifera may structure meiobenthic communities. Oecologia 81:354-360

Daborn GR, Amos CL, Brylinsky M, Drapeau G, Faas RW, Grant J, Long B, Paterson DM, Perillo GME, Piccolo MC (1993) An ecological cascade effect: migratory birds affect stability of intertidal sediments. Limnol Oceanogr 38(1):225-231

Freund RJ, Littell RC, Spector PC (1986) SAS systems for linear models. SAS Institute Inc, Cary, NC

Glassom D, Branch GM (1997) Impact of predation by greater flamingos Phoenicopterus ruber on the macrofauna of two southern African lagoons. Mar Ecol Prog Ser 149:1-12

Grassle JF, Sanders HL (1973) Life histories and the role of disturbance. Deep Sea Res 20:643-659

Mazure HGF, Branch GM (1979) A prelminary analysis of bacterial numbers and biomass in Langebaan lagoon. Trans R Soc S Air 44(1):43-54

This article was submitted to the editor
Mills ED (1966) The biology of an ampeliscld amphipod crustacean sibling species pair. J Fish Res Bd Can 24(2): 305-355

Plante R, Alcclado PM. Martinez-Iglesias JC, Ibarzabal D (1989) Redox potential in water and sediments of the Gulf of Batabanfró, Cuba. Estuar Coast Shelf Sci 28:173-184

Probert PK (1984) Disturbance, sediment stability and trophic siructure of soft bottom communities. J Mar Res 42 : 893-921

Reidenauer JA (1989) Sand dollar Mellita quinquiesperforata burrow trails: sites of harpacticoid disturbance and nematode attraction. J Exp Mar Biol Ecol 130:223-235

Reise K (1979) Moderate predation on meiofauna by the macrobenthos of the Wadden Sea. Helgol Meeresunters 30: $263-271$

Reise K (1985) Tidal flat ecology. Springer-Verlag, Berlin

Rhoads DC (1974) Organism-sediment relations on the muddy sea floor. Oceanogr Mar Biol Annu Rev 12: $263-300$

Rhoads DC, Young DK (1970) The influence of deposit feeding organisms on sediment stability and community trophic structure. J Mar Res 28(2): 150-178

Sherman KM, Coull BC (1980) The response of meiofauna to sediment disturbance. J Exp Mar Biol Ecol 46:59-71

Tibbles BJ (1991) Report on estimates of bacterial productivity in the sediments of Walvis Bay Lagoon. Unpublished report to EMATEK, Council for Scientific and Industrial Reseach (CSIR), Stellenbosch

Velji MI, Albright LJ (1986) Microscopic enumeration of attached marine bacteria of seawater, sediment, fecal matter and kelp blade samples following pyrophosphate and ultrasound treatment. Can J Microbiol 32:121-126

Webb DG, Parsons TR (1991) Impact of predation-disturbance by large epifauna on sediment-dwelling harpacticoid copepods: field experiments in a subtidal seagrass bed. Mar Biol 109:485-4.91

Walters K, Moriarty DJW (1993) The effects of complex trophic interactions on a marine microbenthic community. Ecology 74(5):1475-1489

Wynberg RP (1991) The ecological effects of collecting Callianassa kraussi Stebbing and Upogebia africana (Ortmann) for bait: impacts on the biota of an intertidal sandflat. MSc thesis, University of Cape Town

Manuscript first received: October 5, 1993

Revised version accepted: February 3, 1997 